stronger than humans, but deduces from his anthropocentric items that human evolution has occurred at about 10 times the rate of ape and monkey evolution.

How easy it would be to argue the contrary from the chimpanzee point of view: that we are a most retrograde species who have lost our body hair, facility in climbing trees, female sexual swellings and numerous other primate assets. A more neutral description would merely state that we are adapted to a way of life very different from the ancestral one, and that small changes at the molecular-genetic level can obviously result in major phenotypic and behavioural modifications.

The mystery of the big human brain and what goes on inside it intrigues Wills, as it has fascinated so many others.

The last few chapters, some of the best in this book, deal with the genetic aspects of diseases such as narcolepsy, attention-deficit hyperactivity disorder, schizophrenia, Alzheimer's disease and the much-debated factors in IQ. He speculates that rapid generational changes in microsatellite DNA which are known to account for several neurological diseases, such as Huntington's chorea - could be a mechanism for intellectual improvement. In Wills's opinion, our grandchildren will surely be smarter than us, and within a few generations Einsteins and Mozarts will be commonplace.

These optimistic exegeses, while not without interest, illuminate by omission how little we understand about the molecular, functional and adaptive factors that have

\section{Blast from the past}

This satellite image shows an unusual view of Mount St Helens and the area around it, 11 years after the 1980 eruption. Winds of up to $440 \mathrm{kph}$ flattened a wide area and lava fanned out from the volcano, leaving what is now a horseshoeshaped crater, lower left, containing a lava dome 300 metres high. Faint traces of green in the purple lava show the regrowth of vegetation, especially in protected valleys. It is one of the many dramatic computer-generated digital images, obtained by satellite sensing systems, in America from Space by Thomas B. Allen (Firefly, \$29.95). inflated the human cranium and its contents threefold over the past five million years.

In his last chapter, "Our evolutionary future", Wills unhesitatingly predicts an even bigger-brained advent that will carry us beyond the Solar System to planets of other stars. I admire the courage of someone who can make such projections for a society that cannot predict the next election result or the weather next week.

Are we still evolving? This is the question Wills asks at the beginning and end of his volume, and at many points in between. The answer is, of course, that we are: as are chimpanzees, gorillas, orang-utans, crocodiles and bacteria. Are we really evolving much faster than those other organisms? Not at the molecular level, according to present evidence. Even bacteria, the oldest and most 'primitive' forms of life, show a degree of flexibility in their ability to survive and become resistant to our most potent antibiotics that our own species has yet to prove it can match.

In Darwin's concept of evolution, the direction of evolutionary change is unpredictable, dependent as it is on changing conditions and the vagaries of natural selection. Wills's confidence as to which evolutionary features are good or bad, superior or inferior, faster or slower, conveys perhaps a hint of Promethean hubris.

For the future of the species, let's hope that our grandchildren will, as Wills predicts, be smarter than we are.

Adrienne Zihlman is in the Department of Anthropology, University of California, Santa Cruz, California 95064, USA.

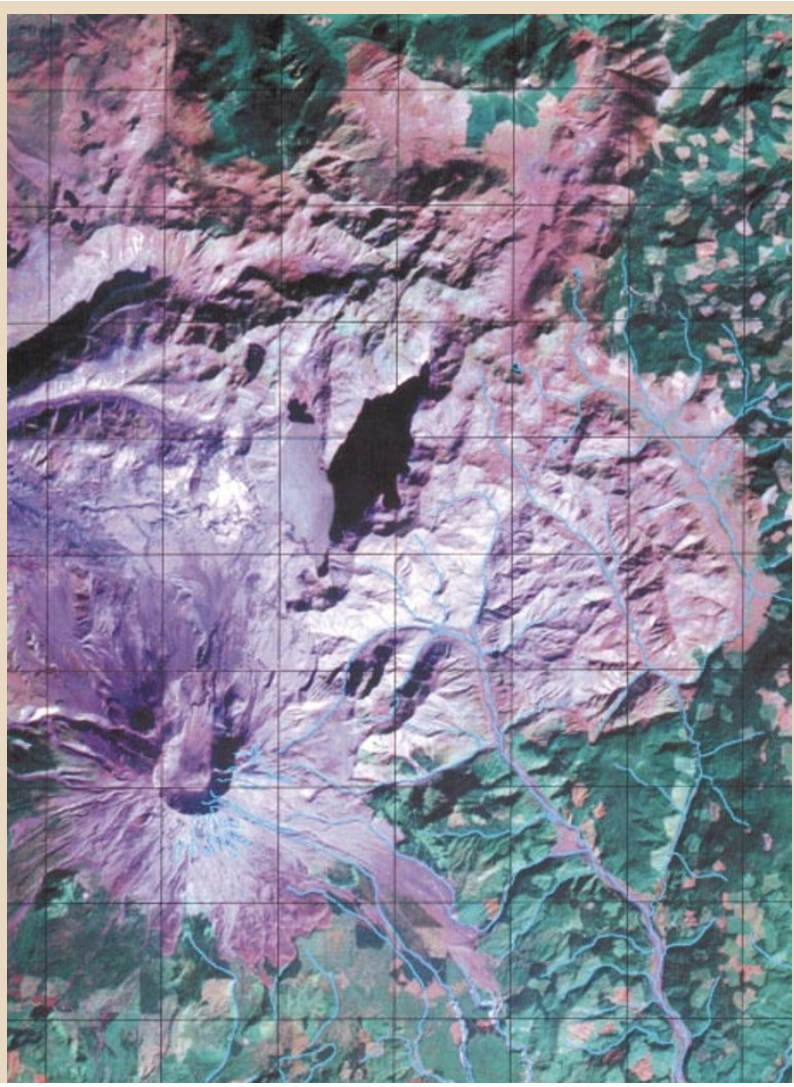

^ ๔ 1999 Macmillan Magazines Ltd
A most uplifting

\section{career}

\section{Out of the Crater: Chronicles of a Volcanologist}

by Richard V. Fisher

Princeton University Press: 1999. 178 pp.

$\$ 24.95, £ 16.95$

\section{Steve Sparks}

The life of an academic field geologist, especially one interested in volcanoes, has considerable attractions. Pleasures to be found include visiting beautiful and sometimes remote parts of the world, and enjoying the companionship of like-minded colleagues, the inevitable adventures and mishaps, and the intellectual challenges of interpreting the tantalizing clues nature provides on how the Earth works. Richard Fisher, professor of geology at the University of California, Santa Barbara, is among the foremost volcanic geologists of the second half of this century. Out of the Crater is essentially his reminiscences.

The book makes interesting and entertaining reading because of the richness of Fisher's experiences and the spectacular nature of his subject. Each short chapter includes anecdotes and descriptions of the parts of the world he has visited, occasional explanations about the science of volcanology and some insights into how he developed his scientific ideas. The reader will be taken to some of the world's great volcanoes - such as El Chichón in Mexico, Vesuvius and Mount St Helens and to diverse cultures: the American West, Argentina and China.

Fisher's unique formative experience was within the context of a remarkable episode in twentieth-century history. In 1946, at 17 years old, he was stationed in the army at Los Alamos and volunteered to go to Bikini atoll, where he observed the atomic bomb tests. His descriptions of the Bikini tests are fascinating, and highlight the military authorities' almost complete lack of understanding of the lethal and long-term effects of radioactivity. To swim in the ocean at Bikini atoll a few days after the test now seems incredible.

What made the Bikini experience so important for Fisher's later scientific achievements was seeing the base surge phenomenon - the cloud of radioactive dust and water droplets that spreads radially along the ground from the base of an atomic explosion. Fisher's significant contribution to volcanological science has been the elucidation of the geology of pyroclastic density currents, a term that encompasses volcanic base surges, pyroclastic flows and volcanic blasts like that of Mount St Helens in 1980.

When volcanic base surges were first recognized, Fisher realized the significance immediately. The enigmatic sedimentary structures in many pyroclastic sequences, 


\section{New in paperback}

\section{Cats' Paws and Catapults: Mechanical} Worlds of Nature and People

by Steven Vogel

Penguin, £8.99

"Vogel's book has been written to be enjoyed... It is full of ideas and well-explained principles that will bring new understanding of everyday things both to non-scientists and scientists alike". R. McNeill Alexander, Nature 392, 881 (1998).

\section{The Number Sense: How The Mind} Creates Mathematics

by Stanislas Dehaene

Penguin, $£ 8.99$

"Our ability to use numbers is as much a fundamental aspect of what makes us human as is our ability to use language. This book provides an excellent introduction to how this ability is organized in our mathematical brain." Brian Butterworth, Nature 391, 856 (1998).

\section{Volcanoes: Crucibles of Change}

by Richard V. Fisher, Grant Heiken

and Jeffrey B. Hulen

Princeton University Press, $\$ 19.95, £ 14.95$

\section{Twins And What They Tell Us About \\ Who We Are}

by Lawrence Wright

Wiley, $£ 14.95$

"As a measured analysis of a complex and

controversial field, it is not very good... The book

which were commonly dismissed as reworking, were primary features of volcanic flow.

Fisher generously acknowledges that the credit for seeing the link between the atomic base surges and volcanic phenomena belongs to Adrian Richards, who briefly noted the similarities in 1959, and to Jim Moore of the US Geological Survey, who developed the insight in detail. However, it was principally Fisher who pioneered the systematic documentation and interpretation of the deposits of base surges with colleagues and students such as Aaron Waters, Hans Schminche and Grant Heiken. This exciting and important period in volcanic geology is described with the insights into the twists and turns of original discovery that are usually missing from scientific papers.

Later in the book, Fisher also describes in characteristically modest fashion his important discoveries and ideas about pyroclastic processes such as ash-cloud surges, flow transformations and the expanded character of some pyroclastic flows.

Volcanology can be a dangerous profession. The most poignant part of the book concerns the deaths of two outstanding young American scientists by volcanoes just as their careers were blossoming. When Mount St Helens started to erupt in 1980, Harry Glicken was stationed at the Coldwater II observation post, six miles north of the volcano. Glicken is essentially a collection of the sometimes divergent views of the field's main players about the significance of genes." John Galloway, Nature 392,34-35 (1998).

\section{Why People Believe Weird Things: Pseudoscience, Superstition and Other Confusions of Our Time}

by Michael Shermer, with a foreword by Stephen Jay Gould

W. H. Freeman, £10.95, $\$ 14.95$

"Shermer refuses to engage deeply with why beliefs are held. ... In the Middle Ages it took the rack and the thumbscrew to make people confess that their father drank babies' blood. Now, a couple of sessions in an air-conditioned psychotherapist's office seems to suffice. What needs explaining is how we have become such wimps.” John C. Marshall, Nature 389, 29 (1997).

\section{Rethinking Visual Anthropology}

edited by Marcus Banks and Howard Morphy Yale University Press, \$18, £12.95

\section{Space and The American Imagination} by Howard E. McCurdy

Smithsonian Institution Press, \$17.95, £10.95 "McCurdy, an acknowledged authority on the US space programme ... tells a richly detailed and persuasively balanced story that explains the paradox of manned spaceflight." Alex Roland, Nature 392, 143-145 (1998).

had a meeting with Fisher on 18 May to discuss his career and so David Johnston took over his duty. The catastrophic eruption of that day killed Johnston. Eleven years later, Glicken was killed by a pyroclastic flow on Mount Unzen in Japan along with the film-makers Katia and Maurice Kraft and many journalists.

Pyroclastic density currents are the most lethal of volcanic phenomena. As this book reminds the reader, advances in understanding the geology of these deposits (in which Fisher himself has played a leading role) have established the criteria for identifying them which is an essential part of volcanic hazard and mitigation work.

Fisher is a good writer and mixes tales of his travels, science and personal anecdotes well. The book is entertaining and an easy read. Geologists will enjoy the book because they will be reminded of their own escapades. Young people contemplating a geological career will surely also be seduced by the idea of a slightly anarchic life in remote and beautiful parts of the world. Fisher has clearly been motivated by the wonder of nature and the fundamental desire to understand its mysteries that drives many successful natural scientists. Perhaps the only regret is that the book is not a bit longer.

Steve Sparks is at the Chiron Corporation, D-207Q, Emeryville, California 94608, USA.

\section{Speaking in tongues}

The Neurolinguistics of Bilingualism: An Introduction

by Franco Fabbro

Taylor \& Francis: 1999. 255 pp. £39.95

\section{Risto Näätänen and Teija Kujala}

The past few decades have seen our exposure to multiple languages continuously increasing. In this sense, Franco Fabbro's Neurolinguistics of Bilingualism, dealing with the representation and processing of multiple languages in the brain, meets an urgent need. Another major factor underlining the importance of this research field is that bilingualism is by no means unusual. If we define it in the broad sense - to include not only people who from an early age have spoken two or more languages, but also those who master a foreign language to a certain extent or a language in more than one dialect then bilingualism covers more than half of the world's population.

The main message of the book is how lesions in various parts of the brain affect the comprehension and production of languages. Important questions are addressed, such as what happens to the native language compared with those acquired later in life when certain parts of the brain are damaged, or, if these languages are lost, which of them recovers first or to the greatest extent. The cases described elucidate not only bilingualism, but also, more generally, the fascinating complexity of human cognitive brain functions.

A great strength of the book is that it is organized in an extremely reader-friendly way. It starts with a general introduction on what language is and how the acoustical analysis and production of speech take place. This is followed by an introduction to the functional anatomy of the brain. The reader is also briefly introduced to technologies and means of studying cognitive brain functions and assessing language-related dysfunctions. This introductory part makes the rest of the book comprehensible to readers who do not have a solid knowledge of the brain's functional neuroanatomy. Without such an introduction, the main part of the book, which attempts to explain bilingualism from observations on patients with brain lesions causing various forms of aphasia and dysphasia, might be hard for readers outside the field of neuroscience to understand.

The case reports - describing how language functions can be affected by a brain lesion, and how these functions are recovered - are interesting and very helpful for understanding how multiple languages are represented in the brain. But this emphasis on brain lesions makes the book somewhat onesided and is problematic for several reasons. 